\title{
THE TRADITION OF PLINY'S LETTERS
}

\section{By Elmer Truesdell Merrill}

It is my purpose to attempt in these pages a mere outline sketch, therefore without much argument, of the tradition of Pliny's Letters i-ix from the time of their first appearance down to the era of the early printed editions. Where I could I have avoided the duplication of discussion by referring to articles already published.

Jean Masson in 1709 was apparently the first scholar to undertake seriously and in detail an investigation of the chronology of Pliny's life and writings. His conclusions, faulty as they were, held sway until Theodor Mommsen established more scientific ground by an examination of the dates of the individual books and letters. Mommsen's (not always justifiable) determinations have served as the text for later discussion by Stobbe, Gemoll, C. Peter, Asbach, Schultz, H. Peter, as well as, in single points, by other critics. All of these writings can be conveniently found from the bibliographical references in Bursian's Jahresbericht and Klussmann's supplement to Engelmann-Preuss, and in the third edition of Schanz's Geschichte d. röm. Litteratur, and need not be here cited more specifically. In general it seems to me likely that the individual books did not each contain letters exclusively of a certain year or years, any more than that strict chronological order was observed within each book. All that it appears safe to say is that the nine books of miscellaneous letters, brought into literary form and perhaps purged of all matter of merely temporary interest, were finally issued by Pliny, not singly, but in three or four groups (perhaps i-ii, iii-vi, vii-ix) at successive intervals between the years 97 or 98 and 108 or 109 . Thus the whole corpus was completed and published before Pliny set out on his journey to Bithynia.

On the date and history of the unique book of correspondence with Trajan I will not speak specifically, though I must make a few necessary remarks farther on; here I will merely refer to my brief articles elsewhere printed ("Zur frühen Überlieferungsgeschichte des [Classical Philologr X, January, 1915] 8 
Briefwechsels zwischen Plinius und Trajan," Wiener Studien, XXXI [1909], $250 \mathrm{ff}$; ; "On the Early Printed Editions of Pliny's Correspondence with Trajan," Classical Philology, V [1910], $451 \mathrm{ff}$.$) .$

His own letters assure us that, while Pliny was yet living, these pleasant and graceful literary exercises of his were widely disseminated and read in the Roman world; nor is it doubtful that after his death they still found admirers. Nothing would appear more natural than that especially the letter-writers of the following centuries should be influenced by them. But despite the hopefulness of modern students of these matters, it appears impossible to substantiate the existence of such influence by citing imitation, except in the case of one man, Apollinaris Sidonius. Fronto, for example, shows no indication of acquaintance with the works of Pliny, and it is idle to imagine that the publication of his letters must in itself be accounted evidence of the influence of the earlier writer. Symmachus has been repeatedly cited in recent days as an imitator of Pliny. But the influence is not to be detected in the context of the letters of Symmachus or certified to by any quotation from Pliny. It consists, if at all, in the alleged fact that the letters of Symmachus were finally edited in nine books. But even this is not surely the case. The arrangement into books seems to be due to his son, and not to himself, which would, to be sure, merely remove the trace of possible influence one generation farther on. But the principle of arrangement within the books is quite different from that followed by Pliny, while an imitator in editing, as the younger Symmachus is claimed to be, would surely be likely to carry his imitation farther than the mere number of the books. And finally, even though recent editors have seen fit to assign the concluding letters of the long series to the ninth book, there is MS authority for counting them as a tenth book, possibly truncated by the loss of some letters at the end. Yet another bit of confirmatory evidence may be drawn from the attitude of Apollinaris Sidonius, who professedly adopts Symmachus and Pliny as his models of style (Epist. i. 1. 1). His quotations and imitations of both are very numerous; his admiration appears to be equally divided between them; but, when he wants a precedent for issuing a ninth book of letters to supplement the preceding eight (Epist. ix. 1. 1), he finds it in the example of Pliny alone, 
who thus completed his collection (Sidonius surely had no knowledge of the existence of any Trajan correspondence). It is very unlikely that if he could have quoted the equal authority of his other model, Symmachus, he would have failed to do so. I am therefore led to believe that no trace of acquaintance with or influence from Pliny is legitimately to be found in Symmachus.

Macrobius, to be sure (v. 1. 7), represents his character Eusebius as mentioning Pliny and Symmachus in the same breath as examples of the genus dicendi pingue et floridum; but Macrobius very evidently has in mind, not the Letters at all, but the Panegyric, which is also plainly referred to a century later by Cassiodorius (Var. 8. 13), in a passage which has even been understood to concern the correspondence with Trajan!

Sidonius, whom I have just had occasion to mention as a striking imitator of Pliny, speaks as if the nine books of the Letters were well known in his time and region. In Pliny's own day, indeed, copies had been sold in Lyons, the birthplace of Sidonius (Plin. Ep. ix. 11), and Gaul was in this later century the rallying-point of culture. Pliny may well have been known there by his Letters when he was not so known to Symmachus.

But the example of Sidonius does not seem to have had any effect upon the letter-writers of the centuries that follow, whose works have come down to us. To be sure, there has been great solicitude on the part of the moderns to discover such indications of reading and imitation. Salvianus, who in the middle of the fifth century wrote some theological treatises and appended nine letters to them, has been fondly imagined to have cherished therein some reminiscence of Pliny's nine books. Still more has been done for Ennodius, whose 297 letters, given in a single series in the MSS, were divided into nine books (of course after Pliny's model) by Sirmond, their Parisian editor, in 1611. Neither Salvianus nor Ennodius, any more than any of the rest of the epistolographers except Sidonius, betrays any knowledge of Pliny's Letters.

Of other references during the early Middle Ages there are just two classes: (1) mention of the persecution of Christians in Bithynia (Plin. Trai. 96, 97), and (2) brief biographical reference under the professed date of his death in various chronica. All the former are 
directly borrowed from Eusebius, who in turn copied from Tertullian (Apol. 2), who surely never saw the Letters himself; all the latter are copied from the Eusebian chronicles, or from Jerome's version, and so date back possibly to Suetonius. None are due to any contemporary knowledge of the Letters. Between the date of Sidonius (ca. 430-80) and that of Ratherius (890-974) no direct or indirect mention of Pliny's Letters occurs in any published works. For the basis of reconstruction of their history during the intermediate period we must turn to the extant MSS of the Letters themselves, and draw from them such inferences as appear reasonable.

The obviously rhetorical character of the Letters, written with an artifice that was at any rate much more sympathetic to the tastes of a revived scholasticism than was the style of Cicero's correspondence, or even that of the letter-essays of Seneca, admirably adapted them to the study of the rhetoricians of the fourth to the sixth centuries. To this period, when the revision and editing of earlier popular authors revived certain of the traditions of Alexandrian days, must probably be assigned the origin of such a sophisticated text of Pliny's Letters as is represented by one family of MSS (MV, etc., the "nine-book family"; cf. A. Otto, "Die Überlieferung der Briefe des jüngeren Plinius," Hermes, XXI [1886], $287 \mathrm{ff}$.$) . It is possible$ that this was the work of a single scholar; but no subscription attests it, such as MSS of certain other authors still retain. It is possible that the process of emendation extended over a considerable period of years, and was carried out by a succession of hands. At all events, when allowance has been made for such incidental and isolated error and emendation as any MS of any reasonably late age is likely to show, the remaining mass of relevant variants is of such a uniformity of characteristic as to suggest that it was due to persons of a single school, as it may be called, if not to a single person.

The "nine-book family" of MSS is of course judged to be in its present condition the result of a studious and reasonably consistent course of emendation, from a comparison of its readings with those of a second family (PBF, etc., the "ten-book family"). This tenbook family also offers, along with numerous enough copyists' blunders of the usual sort, some examples of evident emendation. It is conceivable that a competent scholar might judge, somewhat 
as Keil did (and Keil's merits are indisputable), that the nine-book family presents in general a sincere text, and the ten-book family a scholastically emended text-at any rate a less correct text. So much, however, ought at any rate to appear certain, that the families differ so frequently, and in such a manner, that if one family is sincere, the other is definitely sophisticated. The differences can hardly be rationally accounted for by the postulation in both cases of only the usual amount and character of textual error in copying and incidental emendation in after-study. Keil does not appear to have faced the problem at all in this way. He knew, indeed, in 1870 far less about the tradition of the "ten-book family" than is known today; and he appears merely to have judged in general that the excellently reading text supported by well-executed ninthcentury MSS was far superior on the whole to the text supported by a single tenth-century (as he wrongly judged it) MS (F, S. Marci) and a few readings from a lost MS of uncertain age and relationship to the other, along with the doubtful testimony of Aldus. The state of the "ten-book" text is now better known by the rediscovery of the older lost codex (B, Beluacensis, uel Riccardianus) and the more extended knowledge of still another lost MS of the same family ( $\mathrm{P}$, Parisinus), which both Budaeus and Aldus used. The decision of the dilemma cannot be made to rest on any demonstrative evidence; it cannot depend upon the comparison of a few variants between the two families, such as could be quoted here; it must be settled by weighing the mass and character of the variants on either side. Further discussion of details must be omitted in this outline sketch. Decision will be helped by a consideration of the long list of examples selected by Otto in the article cited above; it will be more facilitated by a careful examination of all the variants in such an apparatus criticus as my forthcoming edition of Books $\mathrm{i}-\mathrm{ix}$ will furnish. ${ }^{1}$ But full examination will hardly fail to convince the unprejudiced observer (as Otto was convinced) that the nine-book

1 I may be permitted to say here that the complete manuscript of this book, the preparation of which was delayed more years than I like to reckon by difficulties in the way of sufficient journeys to Europe, was put in Teubner's hands in March, 1913. After delays due to the printers had long enough interfered with the final stages of the publication, the intervention of the present war has put a stop to progress for an indefinite time to come. 
family, and not the ten-book, gives the scholastically emended form of the text.

As I take it, then, one or more MSS of the Letters fortunately escaped the hands of the studious emendators of the early MiddleAge revival of learning, and carried forward to later centuries a substantially unrevised text, which is represented for us by the ten-book family (PBF, etc.). It will be noted that I am quite unable to agree with the theory of Kukula (see the preface to his edition of the Letters in the Bibliotheca Teubneriana) that both the nine- and the ten-book families show the result of scholastic revision, but in different ways, the nine-book family substituting in very numerous cases other words for those of Pliny's choice, but scrupulously retaining the order of the words within the phrase, while the ten-book family adheres with accuracy to the Plinian vocabulary, but has not hesitated to change at will the order of the words. This sort of a via media appears to me quite delusive. It furnishes, to be sure, for the following of critics in the constitution of the text an easily worked practical rule, which amiably appears to avoid the difficulty of a direct and general verdict in favor of either family against the other, while yet it includes both under condemnation. But that, I concede, is not the important point. The important point is this: granted that a text is to be submitted in, say, the fifth century to a formal rhetorical revision, what scholars of that time would be likely to venture a tolerably bold alteration of words, and yet fear to touch the order of the words? Or what other school of revision would assail the order of words, but leave the words themselves chivalrously unharmed? What proved precedent is there that should justify us in postulating such a pair of similarly limited but substantially diverse critical tendencies? No precedent, surely, is to be found in the known history of text-tradition, and most certainly none in human nature. A scholastic reviser of that period, sitting down to improve a rhetorical text according to the rules of his art, would surely meddle with more than one class of things. Not words only, but the order of words, the turn of phrases, clausulae, and the like, would come within the scope of his emendation. Not two families, in diverse and yet strictly limited ways, but one family only must be judged to show the effects (if either does) of a 
formal revision in the interests of a scholastic rhetoric, and this family must be judged to show it in more than one class of instances. I have before remarked that the comparison of readings appears to free the ten-book family from the charge of extended wilful emendation.

But yet a third family of MSS (the "eight-book family," Dmoux, etc.) has left descendants to our day which exhibit traces of a true ancient tradition. Its readings not infrequently disagree with those of the other two families, and appear on their intrinsic merits to be sometimes right as against each of the others. But in many instances the eight-book family agrees with the nine-book family against the ten-book. On the whole, where there is agreement with one or the other, it agrees more frequently with the nine-book than with the ten-book tradition. This might evidently be explained on various theories. One is that both the nine- and eight-book traditions, in cases of agreement, probably have preserved the true reading independently from an early date, and certify its antiquity, while the ten-book family has corrupted it, by accident or otherwise. But the fact is that in too many instances the agreement of the nineand eight-book families is on readings that appear, in the light of comparison with those of the ten-book family, to fall under suspicion of being the result of the aforesaid rhetorical revision. Therefore it seems more simple and probable, on the theory that the nine-book tradition has been rhetorically revised, to suppose that the eight-book stock branched off from the nine-book during the fifth or sixth century, when the process of revision was under way, but had not yet reached its maximum; or else that at a later period the eightbook text, being in origin antecedent to the nine-book revision, was somewhat interpolated from it.

Either of these last-mentioned alternatives may represent the truth. The former of them is the more probable on account of the common presence in the nine- and eight-book traditions of a considerable number of small lacunae, which could hardly have been introduced by imitation from one into the other. Of course the larger lacunae in the nine-book text alone must have originated after the division of the two stocks; for there is no trace of any interpolation from the ten-book tradition into the eight-book till after 
the rediscovery of the latter in the fifteenth century. The eightbook text appears to have reached substantially its shape as recognized at present by the ninth century, that is, before Ratherius used the eight-book MS at Verona. For further discussion I must refer to an article already printed in this journal ("On the EightBook Tradition of Pliny's Letters in Verona," Classical Philology, $\mathrm{V}, 175 \mathrm{ff}$.), and to another that I hope to print soon on codices $\mathrm{D}$ and $\mathrm{m}$.

To a MS of the most uncontaminated of the three families was appended as a tenth book, perhaps in the seventh or eighth century, the correspondence of Pliny with Trajan. This unique collection had heretofore led an independent existence. It was probably not published in Pliny's lifetime, and all extant literary references to it throughout the whole course of time down to its rediscovery at the opening of the sixteenth century are eventually copied from the single reference in Tertullian (Apol. 2), who was himself apparently not acquainted at first hand with the correspondence, but quoted his somewhat inaccurate statements from a source now unknown (cf. my article in Wiener Studien cited above. A reference in the Chronicon of Prosper of Aquitaine, which a correspondent has kindly called to my attention as a possibly overlooked testimonium, is taken bodily by Prosper from Eusebius-Jerome, who in turn got it from Tertullian). Before the time the Trajan-book was appended to a MS of what from this circumstance I have called the ten-book family, it appears to have acquired a special title for the book as a whole, and a lemma for each of the letters in it; for these indubitably were read in the now lost codex Parisinus, and they would not have been invented and affixed after the book of Trajan letters had been united with the rest, which had no such labels.

Thus we reach the ninth century with three well-marked families of Plinian MSS in existence, but none represented by more than a few codices at best, so far as we can judge from the indications of later as well as of earlier history. Also there is an almost total lack of literary reference, allusion, quotation, or imitation, except for the single valiant instance of Apollinaris Sidonius. Of each of these three families I wish to speak briefly, taking them up in the order in which they came to the knowledge of Renaissance scholars. 


\section{THE TEN-BOOK FAMILY}

Of this branch of the tradition three MSS only can clearly be discerned (BFP), of which two (BF) are still in existence in the Laurentian Library at Florence, but the third (P) disappeared early in the sixteenth century. Codices $\mathrm{B}$ and $\mathrm{F}$ are derived from a common archetype which may probably be referred to the eighth or ninth century, but was already seriously mutilated at the end, or perhaps never completely copied (see F. E. Robbins, "The Relation between Codices B and F of Pliny's Letters," Classical Philology, V, $467 \mathrm{ff}$.). For each codex extends no farther than the sixth letter of the fifth book, and this was doubtless the condition of their immediate common archetype. Yet it had still kept the heading, C. PLINII . SECVNDI . EPISTVLARVM . LIBRI . DECEM, and also indexes to the addresses and first words of the individual letters, compiled from a codex of yet earlier date. The heading and the indexes (through Book v) were faithfully copied, though with some difficulty, by the scribe of $\mathrm{B}$, while the scribe of $\mathrm{F}$, writing at a later date by a century or two, omitted them. On these indexes and certain genealogical questions connected with and suggested by them, see F. E. Robbins, Classical Philology, V, $476 \mathrm{ff}$. The fact that, on account of the omission of iv. $26, \mathrm{BF}$ contain just one hundred letters is surely without special significance.

Where codex B (saec. X) was written, I am unable to state. The question needs decision by a competent paleographer, which I am not. But it certainly existed in the thirteenth century, and probably earlier, in the chapter-library of St. Peter's at Beauvais. The inscription "S. Petri Beluacensis," though erased, can still be read at the bottom of the recto of the first folio, and is apparently of the twelfth century. This is almost without doubt the actual MS that Vincent of Beauvais ( $\dagger 1264)$ ran across there, and used-to no very good advantage (cf. his Spec. Hist. XI. 67). It was appended to a MS by the same scribe, or scribes, of the Natural History; and though Vincent read and excerpted the hundred letters with avidity (and doubtless iii. 5 among them), he could still account the two works to be by one and the same Pliny. At what time and in what manner the MS came to Florence into the Riccardian Library I have been unable to discover. There is no indication that it attracted 
the attention of scholars until 1729, when Kortte was preparing his edition of the Letters (published in 1734). At the request of Jacques Philippe d'Orville, Antonio Francesco Gori collated the MS for Kortte's use, and noted the fact of the collation upon the parchment binding of the book. A copy of Gori's collation, if not the original, I have observed in the Bodleian Library (Summary Catalogue, 16894). Kortte mentioned a number of Gori's readings in his edition, and the MS thereafter rested in peace till about 1830 . The binding was in bad shape. A single attached leaf (as it seems) containing the last part of Plin. Ep. v. 6 had disappeared even before Gori's time, consequent (if we may judge from the unusually worn and soiled appearance of fol. $18^{\mathrm{v}}$, which was left as the last page) upon the loss of the back cover. The Riccardian Library was poorly cared for. So Libri, that infamous thief of so many MS treasures, found little difficulty in ripping the Letters off from the end of the Natural History, and carrying them away to sell with other codices to the English Lord Ashburnham. When his heir, many years afterward, parted with his wonderful collection, Italy bought this back among other purchases, and L. Havet identified it (cf. Havet, Revue critique, XV, $251 \mathrm{ff}$., and Stangl, Philologus, XLV, $220 \mathrm{ff}$. and $642 \mathrm{ff}$.).

Meanwhile Keil had tried to find the MS in the Riccardian and failed; so that the best he could do even in 1870 was to reprint the scanty and often erroneous readings that Kortte had seen fit to excerpt from Gori's collation.

The early history of codex F (saec. XI-XII) is equally unknown. At the time of the revival of learning it was in the library of S. Marco at Florence. Keil imagined (preface to edition of 1870 , p. xi) that it came thither from Lorsch, and was the liber epistolarum Gaii Plinii mentioned in a tenth-century catalogue of Lorsch MSS. But Keil was surely mistaken in supposing $\mathrm{F}$ could have been written as early as the tenth century; and I can find no trace of the existence of MSS of this family in Rhenish lands at anything like this early period. But whatever its source, for three centuries almost all Italian scholars drew their entire knowledge of Pliny's Letters from this one codex. It was repeatedly copied and recopied. Even after Guarino had made known (in 1419) a MS containing eight books instead of less than five, many justly preferred the old text, so far as it went, to the 
new; whence it happens that numerous fifteenth-century MSS of the Letters are now extant which faithfully reproduce the text of $\mathrm{F}$ through v. 6, but from that point on the (always conjecturally emended) eight-book text; in others the eight-book text serves as a basis, but has been more or less freely emended through v. 6 from the F-tradition. Many or all of this last group of MSS (of which oux are examples) are due to the labors of Guarino and his contemporaries.

Codex F itself was somewhat emended in the fifteenth century. Especially the Greek words and phrases in it were not infrequently carefully erased, and rewritten in neat and correct minuscules. But a direct copy of $\mathrm{F}(\mathrm{H}$, Bernensis 136), made in the thirteenth century (not saec. XI-XII, as Hagen's catalogue of the Berne MSS has it), is useful for its preservation of these readings in their original form.

Of codex Parisinus (P), apparently the single MS that preserved the ten books entire till the sixteenth century, and its progeny I may forbear to speak further in this place, since it has been sufficiently treated by Dr. Robbins in the articles cited above, and by myself in articles "On a Bodleian Copy of Pliny's Letters" (Classical Philology, II, $130 \mathrm{ff}$.), and "On the Early Printed Editions of Pliny's Correspondence with Trajan" (ibid., V, 451 ff.). I will merely add here that the Bodleian volume, with its MS supplements and its hundreds of individual readings taken from $\mathrm{P}$ by Budaeus, was lent by its later possessor, Thomas Hearne, to Jean Masson, who mentions the fact, and speaks of the book with some accuracy in his Plinii Vita (p. 165). Mr. E. G. Hardy, who called renewed attention to the volume in 1889, was apparently not aware of this earlier mention by Masson. Aldus came into possession of $\mathrm{P}$ by the kindness of the Venetian ambassador to the court at Paris, and used it enthusiastically but not too rigidly in the preparation of his edition of 1508 . What he did with it then, no one knows. It vanished from sight.

That Aldus described the Paris MS as written "adeo diuersis a nostris characteribus, ut nisi quis diu assueuerit, non queat legere," and "ita antiquum, ut putem scriptum Plinii temporibus," will astonish no one who is acquainted with the vague notions of Renaissance scholars about paleography. If the MS was written, for example, in Beneventan script, or in that which prevailed in northern Italy before the Carolingian reform acquired a footing there, or 
even in uncials, it would have looked different enough from the current fifteenth-century style to appear to Aldus very ancient and very difficult.

\section{THE EIGHT-BOOK FAMILY}

As early as the time of Ratherius (890-974) a MS of Pliny's Letters apparently lay in the chapter-library at Verona, that storehouse of so much that was precious. But for four hundred years nothing further is heard of it. Yet it cannot be doubted that the MS of the Letters used by Johannes de Matociis in the second decade of the fourteenth century, and by the anonymous compiler of the Veronese Flores moralium auctoritatum in 1329 was precisely this same MS, and that this and no other was the MS acquired and exploited by Guarino Guarini in 1419 (see my article in Classical Philology, V, 175 ff.). Guarino was delighted with his new find. He praises it for its extreme and yet vigorous age, the correctness of its text, the number of the letters it included-eight books, when only four and a fraction had been thus far known to the Italiansthe neatness of its page arrangement in three columns. From this last detail L. Traube judged that the MS must have been written in Spain and in uncial characters. I can only add here, with deference to Traube's supreme authority, that I have not discovered in the purer copies of the MS any traces of such an origin suggested by the actual readings; indeed, some textual errors appear to look in another direction.

Guarino in his first enthusiasm praised the text of the codex as excellent ("emendatissimae mihi uisae sunt [sc. epistulae] et, quod non laetitiae solum sed etiam admirationi fuit, in tanta uetustate et aetate iam decrepita nusquam delirare uidentur"). But his transports somewhat abated on further examination. The MS, wonderful though it was for its content, yet evidently did need emendation, and Guarino set about his editorial task of copying and correcting with great zeal and devotion. He will let his friends see the work when he has completed his operations on it; and although, in the correspondence published by Sabbadini, Guarino repeatedly writes of lending the book to others, I do not feel at all sure that he does not usually mean his emended copy and not the original. That disappeared, and has not since been rediscovered. I have sometimes 
been tempted to think that Guarino, knowing that it had been purloined from the Verona library, destroyed it to prevent discovery of the theft. But perhaps it is enough to suppose that, as scholars of his age and a long time thereafter set no particular store upon old MSS as such, but preferred a supposedly more accurate text, even though it had been secured by modern editing, Guarino cast his old MS carelessly aside, when once he had in possession improved copies of it.

From the activity of Guarino and his contemporaries over the new text, numerous copies were spread abroad throughout Italy. Some scholars, as I have before remarked, preferred the F-text through v. 6, and merely supplemented it from there on by the text of the eight-book version; others took the new text as their basis, but substituted through v. 6 more or less readings of the Ftradition (as in oux). Some person of the century even started to add to $\mathbf{F}$ itself the letters from v. 7 on according to the new text, but fortunately desisted before getting fairly under way. Almost all of these fifteenth-century copies display in addition a large and varying number and quality of purely conjectural emendations, due, doubtless, primarily to the initiative of Guarino, and produced yet further in accordance with the notions of the age. But two MSS appear to have been copied from the eight-book Veronensis without being substantially emended. One of these is the elegant piece of penmanship, codex Dresdensis D 166 (D, saec. XV). It gives the complete text that stood in Veronensis, viz., eight books (the eighth being omitted, and the ninth numbered as the eighth) with certain other incidental omissions (i. 8, 12, 23, 24; ix. 16) and dislocations of order within Books $\mathrm{v}$ and ix. These peculiarities it shares in general with all the other eight-book MSS that have not copied as far as it went the F-text, and doubtless drew from Veronensis. That the order in $\mathrm{D}$ is perturbed, and not original, may be inferred with certainty from the concurrent testimony of the two other MS families; for the later discovered codex Mediceus (M) of the nine-book class agrees in the fifth book with the index in B, and in the arrangement and numbering of, and order within, the eighth and ninth books, as well as in the fifth book, with Aldus, who certainly knew nothing of either B or M, and must have taken his order from 
P. That the text of D has not suffered a fifteenth-century course of emendation is inferred from a comparison of the general mass of variants between it and the other eight-book MSS-just such a process (and even more convincing) as leads to the verdict concerning the earlier emendation of the nine-book family.

The second example of an unemended copy of Veronensis is not an elegant book, but a mere little scratchy notebook of miscellaneous brief copies, such as many that are still extant, which fifteenthcentury scholars who were not calligraphers made more or less hastily for their own use. It is a Venetian codex (m, Marcianus Lat. class. XI. 37, saec. XV), and contains among other matter the best text known to me of the "Breuis Adnotatio de duobus Pliniis," which it doubtless took directly from the autograph of Johannes de Matociis prefixed to the Veronese codex, followed by the first book of Pliny's Letters in a text closely agreeing with that of $\mathrm{D}$, but plainly (as may be seen, among other evidence, by examination of lacunae in $\mathrm{D}$ as compared with $\mathrm{m}$ ) copied not from $\mathrm{D}$ but from D's archetype-that is, from Veronensis. Of $\mathrm{m}$, as of $\mathrm{D}, \mathrm{I}$ intend to speak on another occasion. There are traces of yet other MSS with readings like $\mathrm{D}$, but they may be passed over for the present.

The first printed edition of the Letters (1471) was an eight-book text of the type of the Guarinian recension. Whether this printed book itself, or merely such MSS as it followed (they were plenty enough before the end of the century), was the basis of several later printed editions before 1500, can hardly be determined. At all events only the Roman edition of Schurener (1474) and that of Pomponius Laetus (1490) used other materials than the F and Guarino texts. Beroaldus in 1498 practically reproduced the text of Laetus with some emendations of his own. Catanaeus followed Laetus and Beroaldus in 1506.

\section{THE NINE-BOOK FAMILY}

The scholastically revised text that dates from the fifth or sixth century apparently migrated bodily in early days to Germany, where it played a prominent part, as $\mathrm{F}$ did in Italy. Traces of the text appear in several places, though it is not likely that it was often 
reproduced; for mediaeval library catalogues here and there mention the Letters, but, except for a few excerpts and two codices, one incomplete toward the end of the ninth book (M) and the other containing only Books i-iv (V), no one of those active Italian travelers of the fourteenth and fifteenth centuries who searched the country to secure Latin MSS was able to find any copy of the Letters.

But in the course of the fifteenth century there was also a current setting northward from Italy, and MSS of the eight-book text, into which had already been incorporated readings from the Ftradition, crossed the Alps, and were there further corrected by readings from the nine-book text there prevalent, and especially were supplemented by the text of the eighth book, which was still unknown in Italy. This eighth book was naturally appended to the eightbook MSS and numbered as the ninth. It was a MS of this mixed order, imported into Italy, that Schurener, a printer from Boppard on the Rhine, substantially reproduced in his edition printed at Rome in 1474 (r). Unfortunately this MS, or rather its archetype, had lost some sheets in the most valued part of the book (containing viii. 8. 3-18. 11). Schurener's MS copy, as usual, vanished; and no codices of the sort had been noticed by scholars till my pupil, Miss Dora Johnson, whose sudden death shortly thereafter ended a promising career, discovered three, Taurinensis 297 (t), Chigianus H. V. 154 (c, which formerly belonged to Francesco PiccolominiPope Pius III, †1503), and Oratorianus 34 (n, Neapolitanus; see Miss Johnson's classified list of MSS of the Letters in Classical Philology, VIl, $66 \mathrm{ff}$.). All of these MSS exhibit the same great lacuna in the eighth book as the Roman edition (r). Of the three codices, $t$ appears most interesting as having preserved more readings of the German tradition than c. Both contain some of the readings which attracted the attention of Keil in 1870 in the edition of Laetus, and led him to the accurate remark (preface to his edition, p. $x x$ ) that Laetus must have had before him a MS of the same class as that used by Schurener in 1474, but a better one. Codex c is more closely related to the immediate archetype of $r$ than is $t$, but is not so much like it as to lead to the conclusion that one was copied from the other. I have seen neither codex $n$ nor a photograph of it; but the few notes about it that Miss Johnson left appear to indicate so 
close a connection with the 1498 edition of Beroaldus that I am inclined to the provisional opinion that it is mainly or entirely a copy of that printed text.

While the course of the text was passing through this history in Germany, another MS of the same nine-book tradition (saec. IX-X) was lying unnoticed in the Vatican Library (V, Vaticanus lat. 38. 64). Pomponius Laetus finally discovered it, and noted many of its readings in the margins of his own copy of the edition of the Letters that had been issued at Treviso in 1483. This particular book from the collection of Laetus, with its numerous marginalia from $\mathrm{V}$ and from a MS of the ctr-class, I hold in possession, having bought it in 1899 from a bookseller in Rome. Laetus had apparently equipped the volume provisionally as copy for the printer of his own edition, which appeared in 1490. It may be not without interest to remark that I also own a copy of the edition of Laetus which bears the indubitable autograph of Lorenzo de'Medici at the top of its first page of the text, and was (I imagine) carried off when the Medici palace at Florence was plundered in 1494.

The earlier provenience of the Vatican codex is yet undetermined, though I suspect it to have been brought down from Germany. Its contents are (in this order) Caesar B.G. i-viii, a fragment of Ethicus, Pliny's Letters i-iv, speeches and letters attributed to Sallust. Professor B. L. Ullman has recently made to me the interesting suggestion that the archetype of V, if not the MS itself, may possibly be mentioned in the catalogue (ca. 1200) of the Korvey collection printed by Becker in his Catalogi bibliothecarum antiqui, p. 282 (136. Corbeia), where there is recorded, "191. historia Gaii Caesaris belli Gallici.-192. cronica eiusdem cum quibusdam epistolis.-193. Philippicarum." It should be noted that in V no general title is prefixed to the four books of Letters ascribing them to Pliny.

No other MS akin to $\mathrm{V}$ was known to the Italians up to the end of the fifteenth century. But quite certainly from Korvey came about 1508 that unique MS that has preserved to us, originally within the same covers, not merely the nine books of Pliny's Letters (M, saec. IX), but also the first six books of the Annals of Tacitus. Unfortunately the copyist had become weary in face of the difficulties 
offered by the voluminous Greek quotations in ix. 26, and brought his work to a precipitate end in the eighth section of that letter. The MS was acquired by Pope Leo X (Medici), and later transferred to Florence along with other MSS, and deposited in the re-established Medici Library, where it still is. At some unknown date, however, the Letters were separated from the Annals. The character and history of the MS have been so frequently described and discussed (latest by H. Rostagno, the Laurentian prefect, in his preface to the Leyden facsimile of the Annals-cod. Mediceus 68. I, as well as in the text accompanying the Chatelain and Vitelli-Paoli facsimiles) that I need not here treat of it at length. Philippus Beroaldus, who first edited the accompanying part of the Annals, called the attention of Catanaeus to it, and he used it in the preparation of his second edition (published in 1518; see his prefatory epistle). The two codices $\mathrm{M}$ and $\mathrm{V}$ exhibit (so far as $\mathrm{V}$ extends) the same considerable lacunae, but that $V$ is not a copy of $M$ (Keil erred in thinking that it might possibly be older than $M$ ), but is rather of a common descent, may be readily seen by the comparison of even a brief selection of readings: e.g., in i. 7. 1 the Homeric quotation; i. 12. 1 facilis $\mathrm{M}$ fatalis (corrected by first hand from falis, which was apparently the archetypal reading) V; i. 12.12 doleo $\mathrm{M}$ doleo doleo (rightly )V; ii. 11.1 per om. $\mathrm{M}$, add. V; ii. 14.8 potui om. $\mathrm{M}$, $a d d . \mathrm{V}$; iii. 7.12 Piso pater om. $\mathrm{M}$, $a d d . \mathrm{V}$; iii. 16.3 pari om. $\mathrm{M}$, add. $\mathrm{V}$; iii. 5. 16 inquid horas non impenderetur (this last word corrected by second hand from impederetur; a later hand added the sign of an omission, and in the margin wrote desunt) $\mathrm{M}$ inquid non perdereperireenim arbitrabatur quiaquid studiis non impenderetur $\mathrm{V}$.

Two other extant MSS bear testimony to the existence of the nine-book text in the same geographical region; Monacensis (olim Ratisbonensis Emmeramus) 14641 (saec. IX), which, among other miscellany, contains Ep. i. 6 and vi. 10, and Leidensis Vossianus Lat. 98 (saec. X), in which a copyist has written out i. 1-2. 6, partly in Tironian notes.

But a more unhappy fate overtook the nine-book tradition in German lands. Some of the letters were lost, the rest confused in order and in arrangement by books, the text depraved. Of this 
class are codices Pragensis XIV. A. 12 and Harleianus 2497 (olim Cusanus). Titze waxed delirious over the virtues of the Prague MS in the preface to his edition printed in 1820 (not 1823, as the date stands in Keil), claiming it to be a copy of a Visigothic MS of the fifth century, which was itself transcribed from a codex of Pliny's own time. Therefore he believed the disordered selections of the Prague MS to represent the first, quasi-autographic, edition of the Letters as issued by Pliny himself! The Harleian codex was secured by Robert Harley from the curators of the Hospital foundation of Nicolas Cusanus at Cues on the Moselle, doubtless as one item in that beautiful operation of exchange which a modern collector might well envy, whereby Harley gave the curators for their library certain fine, spick-and-span, Basel-printed folios, and took as an equivalent some of their old, worn-out, illegibly handwritten affairs! I ran across the Harleian codex in the British Museum in 1906. Both the Prague and the London MSS have the same lacunae as MV, but in the former they have been partly filled out afterward from some different source. In Harleianus they are left untouched, and that is accordingly the better representative of its worthless class.

University of Chicago

September, 1914 